\title{
RESEARCH OF THE PROCESS OF LIQUID PHASE SELECTIVE OXIDATION OF 4-AMINOTOLUENE WITH OZONE
}

\author{
Andriy Galstyan ${ }^{1,}$ *, Genry Galstyan ${ }^{1}$, Luibov Timoshyna ${ }^{1}$
}

https://doi.org/10.23939/chcht12.03.341

\begin{abstract}
According to the results of studying of kinetic relationships and mechanism of the process of catalytic oxidation of 4-aminotoluene with ozone in the liquid phase, the basis of the technology of 4-aminobenzyl alcohol and 4-aminobenzaldehyde have been developed. It has been shown that under the ozonation conditions in the solution of acetic anhydride in the presence of sulfuric acid, manganese(II) acetate or its mixture with potassium bromide it is possible to stop oxidation at the stage of forming 4-aminobenzyl alcohol or aldehyde. The technological parameters of the process have been studied and the optimal conditions of the technological process have been set.
\end{abstract}

Key words: 4-acetamidotoluene, catalyst, 4-aminotoluene, oxidation, ozone.

\section{Introduction}

The products of oxidation of amino toluene are widely used in the production of synthetic dyes, medicinal and aromatic substances and pesticides [1-3]. Most classical methods of their production have no future because of technological complexity, harsh synthesis conditions and low coefficients of feed stock processing. These problems can be solved by developing new technologies of oxidation of 4-aminotoluene using ozone, which is an affordable and undiluted oxidant [4-6]. At present, it is known that in the medium of acetic acid in the presence of cobalt(II) acetate methylarenes with high selectivity are oxidized with ozone to the corresponding aromatic carboxylic acids $[4,5]$, the oxidation at the stage of forming corresponding alcohols or aldehydes being impossible to stop. Therefore, the systematic research of ozone reactions with 4-aminotoluene to develop the basis of technological process of manufacturing aromatic products is an actual task.

\footnotetext{
${ }^{1}$ Volodymyr Dahl East-Ukrainian National University

31, Vladimirskaya St., 93000 Rubizhne, Ukraine

*aggaalst@gmail.com

(c) Galstyan A., Galstyan G., Timoshyna L., 2018
}

\section{Experimental}

For the experimental study acetic anhydride of chemically pure grade, 4-aminotoluene of chemically pure grade, 4-acetamidotoluene (white crystalline powder, m.p. $420 \mathrm{~K}$ ) after multiple recrystalization from water, manganese(II) acetate of pure grade, and potassium bromide of pharmacopoeia grade have been used. All reagents were purchased from Synbias Ltd (Ukraine).

\subsection{Synthesis Procedure}

Synthesis of 4-aminobenzyl alcohol (4-ABA). In the reactor with a perforated bottom with the capacity of $500 \mathrm{ml}$ at the temperature of $303 \mathrm{~K} 200 \mathrm{ml}$ of acetic anhydride (AA), $220 \mathrm{~g}\left(1.0 \mathrm{~mol} \cdot \mathrm{l}^{-1}\right)$ of 4 -aminotoluene (4-AT), $47.0 \mathrm{~g}\left(2.4 \mathrm{~mol} \cdot \mathrm{l}^{-1}\right)$ of sulfuric acid and $10.0 \mathrm{~g}$ $\left(0.24 \mathrm{~mol} \cdot \mathrm{l}^{-1}\right)$ of manganese(II) acetate tetrahydrate are loaded. The solution obtained is thermostated at $303 \mathrm{~K}$ and the ozone-air mixture with ozone concentration of $0.68 \mathrm{vol} \%$ at the rate of $60 \mathrm{l} / \mathrm{h}$ is passed through this solution. After oxidation $(3 \mathrm{~h})$ the reaction mass is analyzed for the presence of 4-acetamidotoluene (4-AAT). When the analysis results are negative, the oxidation is stopped and the reactive mass is poured into $1000 \mathrm{ml}$ of water and cooled to $278 \mathrm{~K}$. The solution obtained is extracted by $3 \times 80 \mathrm{ml}$ portions of diethyl ether.

The ether layer is separated and the ether is distilled off. 4-Acetamidobenzyl acetate (4-AABA) is dried to a constant mass in a vacuum desiccator. The dry product is hydrolyzed. In the flask with a reflux condenser under constant stirring the obtained 4-AABA is dissolved in the mixture, which contains $165 \mathrm{ml}$ of ethanol and $60 \mathrm{ml}$ of $10 \%$ hydrochloric acid. In 20 min a precipitate of 4-aminobenzaldehyde (4-ABA) is precipitated, which is filtered off. The filtrate is boiled for $1 \mathrm{~h}$, then cooled to $328 \mathrm{~K}$ and poured onto ice. In $1 \mathrm{~h}$ precipitated $4-\mathrm{ABA}$ is filtered, washed with water to $\mathrm{pH} 6$ and dried. Thus, $1.5 \mathrm{~g}$ of 4-ABA are obtained, the yield relative to the theoretical one is $62.0 \%$; m.p. $333-335 \mathrm{~K}$.

Synthesis of 4-ABA. In the reactor with a perforated bottom at the temperature of $303 \mathrm{~K} 200 \mathrm{ml}$ of AA (acetic anhydride), $220 \mathrm{~g}\left(1.0 \mathrm{~mol} \cdot \mathrm{l}^{-1}\right)$ of $4-\mathrm{AT}, 47 \mathrm{~g}$ 
$\left(2.4 \mathrm{~mol} \cdot \mathrm{l}^{-1}\right)$ of $98 \%$ sulfuric acid, $10.0 \mathrm{~g}\left(0.24 \mathrm{~mol} \cdot \mathrm{l}^{-1}\right)$ of manganese(II) acetate tetrahydrate, and $4.8 \mathrm{~g}$ $\left(0.24 \mathrm{~mol} \cdot \mathrm{l}^{-1}\right)$ of potassium bromide are loaded. The reactor is thermostated at $303 \mathrm{~K}$ and the ozone-air mixture with ozone concentration of $0.68 \mathrm{vol} \%$ at the rate of $60 \mathrm{l} / \mathrm{h}$ is passed through it. In $3 \mathrm{~h}$ of oxidation the reaction mass is analyzed for the presence of 4-AAT.

When the result of analysis is positive, the oxidation is stopped, the reaction mass being poured on $1000 \mathrm{ml}$ of water cooled to $278 \mathrm{~K}$. The precipitate of 4-acetamidobenzylidengiacetate (4-AABDA) is filtered off, washed with cooled water and dried. 4-AABDA is hydrolyzed by mixing with $200 \mathrm{ml}$ of ethanol and $60 \mathrm{ml}$ of $10 \%$ chloric acid. The mixture is left for $0.5 \mathrm{~h}$ at $303 \mathrm{~K}$, then $200 \mathrm{ml}$ of water are added, and it is extracted with diethyl ether. The organic layer is separated in the drip funnel and dried with an aqueous magnesium sulfate. The crude product of yellow color is recrystallized from the methyl chloride-petroleum ether mixture and isolated as hydrochloride by adding the calculated amount of $100 \%$ hydrochloric acid. $17.5 \mathrm{~g}$ of 4-ABA are obtained, the yield relative to the theoretical one is $65.0 \%$; m.p. $345-347 \mathrm{~K}$.

\subsection{M ethods of Analysis}

Ozone concentration in the gaseous phase has been determined by spectrophotometric method using SF-46 [7] spectrometer. The concentration of 4-acetylaminotoluene and the products of its subsequent transformation in solution has been determined by gasliquid chromatography with flame ionization detector on the column of $3 \mathrm{~m}$ length and $4 \mathrm{~mm}$ diameter filled with Inerton AW-DMCS carrier, treated with $10 \%$ solution of $\mathrm{NaOH}$ and covered with the stationary phase Apiezon L in the amount of $10 \%$ relative to the carrier weight under the following conditions: the thermostat temperature according to the program is $373-513 \mathrm{~K}$ for $15 \mathrm{~min}$; the rate of gas carrier (nitrogen) is 1.8; hydrogen 1.8, air $18 \mathrm{l} / \mathrm{h}$. Nitrobenzene has been used as an internal standard. The reaction rate constants of ozone with aromatic compounds have been calculated by the method described in [8].

\section{Results and Discussion}

Earlier it was shown [9] that 4-AT in acetic anhydride in the presence of sulfuric acid is quickly acylated in the process of solution preparation for oxidation and interacts with ozone in the form of 4-AAT. The main reaction products are ozonides - the products of destructing aromatic system, and the selectivity of methyl group oxidation does not exceed $28 \%$.

The reaction of oxidation of methylbenzenes with ozone regarding the methyl group becomes preferable only in the presence of catalysts - the compounds of transition metals or their mixtures with potassium bromide $[6,10]$. Under these conditions ozone no longer destroys the aromatic ring of 4-AAT but reacts with the metal to form an active form of the catalyst which involves a substrate into oxidation regarding the methyl group (Scheme 1).

$$
\begin{aligned}
& \mathrm{ArCH}_{3}+\mathrm{O}_{3} \rightarrow \text { ozonides } \\
& \mathrm{Mn}^{2+}+\mathrm{O}_{3}+\mathrm{H}^{+} \rightarrow \mathrm{Mn}^{3+}+\mathrm{HO}^{\circ}+\mathrm{O}_{2} \\
& \mathrm{ArCH}_{3}+\mathrm{Mn}^{3+} \rightarrow \mathrm{ArCH}_{2}+\mathrm{Mn}^{2+}+\mathrm{H}^{+}
\end{aligned}
$$

\section{Scheme 1}

In terms of catalysis by choosing temperature, solvent, catalyst acylation, and selective oxidation, the conditions for controlling the depth and selectivity of methyl group oxidation of arenes are created.

The catalytic activity of various metals has been studied.

Under the conditions of low temperature oxidation (273-303 K) in the medium of acetic anhydride in the presence of sulfuric acid the maximum catalytic activity is demonstrated by manganese(II) acetate. 4-AAT oxidation selectivity regarding the methyl group achieves $85.5 \%$ in its presence. Among the reaction products 4-AABA $(65.5 \%)$ and 4-AABDA $(20.0 \%)$ have been found; 4-acetamidobenzoic acid (4-AABA) was accumulated after the exhaustive substrate oxidation (Fig. 1).

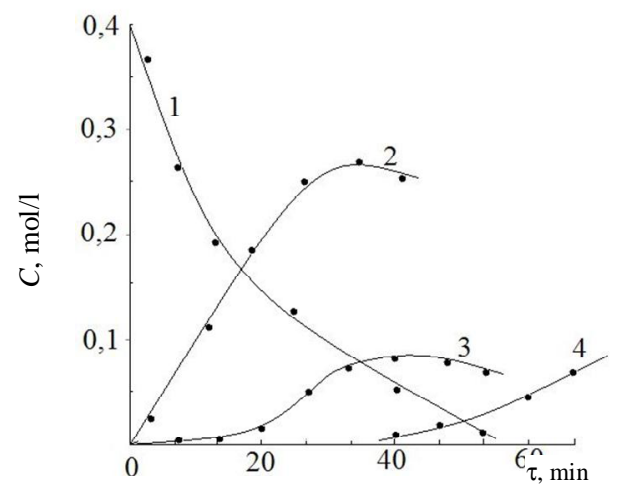

Fig. 1. Kinetics of 4-AAT (1) oxidation in acetic anhydride at $303 \mathrm{~K}$ in the presence of sulfuric acid and manganese(II) acetate: 4-AABA (2); 4-AABDA (3) and 4-AABA (4)

$\left[\mathrm{ArCH}_{3}\right]_{0}=0.4 ;\left[\mathrm{Mn}(\mathrm{OA})_{2}\right]_{0}=0.10 ;\left[\mathrm{H}_{2} \mathrm{SO}_{4}\right]_{0}=1.0$; $\left[\mathrm{O}_{3}\right]_{0}=4.0 \cdot 10^{-4} \mathrm{~mol} \cdot 1^{-1} ; V_{p}=0.011$ 
Table 1

The kinetic parameters of catalytic cycle reactions at 4-AAT oxidation

\begin{tabular}{|c|c|c|c|c|}
\hline \multirow{2}{*}{ Reaction } & \multicolumn{2}{|c|}{$k, 1 \cdot \mathrm{mol}^{-1} \cdot \mathrm{s}^{-1}$} & \multirow{2}{*}{$E, \mathrm{~kJ} \cdot \mathrm{mol}^{-1}$} & \multirow{2}{*}{$A, \mathrm{l} \cdot \mathrm{mol}^{-1} \cdot \mathrm{s}^{-1}$} \\
\hline & $278 \mathrm{~K}$ & $303 \mathrm{~K}$ & & \\
\hline 4-AAT + Mn(III) & $2.7 \cdot 10^{-2}$ & $4.8 \cdot 10^{-2}$ & $22.1 \pm 2.0$ & $8.0 \cdot 10^{2}$ \\
\hline 4-AAT + Mn(II)Br & 0.08 & 0.15 & $31.4 \pm 3.6$ & $6.0 \cdot 10^{4}$ \\
\hline 4-AABA +Mn(III) & $1.1 \cdot 10^{-2}$ & $3.1 \cdot 10^{-2}$ & $31.6 \pm 3.0$ & $2.6 \cdot 10^{4}$ \\
\hline 4-AABA + Mn(III) & $0.2 \cdot 10^{-2}$ & $1.4 \cdot 10^{-2}$ & $33.5 \pm 3.3$ & $2.8 \cdot 10^{5}$ \\
\hline 4-AABDA + Mn(II)Br & $3.3 \cdot 10^{-2}$ & 0.09 & $32.8 \pm 3.0$ & $6.5 \cdot 10^{4}$ \\
\hline 4-AABDA +Mn(II)Br ${ }^{\bullet}$ & $4.2 \cdot 10^{-2}$ & 0.06 & $37.5 \pm 4.0$ & $2.9 \cdot 10^{5}$ \\
\hline $\mathrm{O}_{3}+4-\mathrm{AAT}$ & 0.56 & 0.85 & $16.9 \pm 2.0$ & $8.4 \cdot 10^{2}$ \\
\hline $\mathrm{O}_{3}+4-\mathrm{AABA}$ & 0.26 & 0.48 & $18.7 \pm 2.0$ & $1.6 \cdot 10^{3}$ \\
\hline $\mathrm{O}_{3}+4-\mathrm{AABDA}$ & 0.23 & 0.36 & $20.9 \pm 2.0$ & $3.1 \cdot 10^{3}$ \\
\hline $\mathrm{Mn}(\mathrm{II})+\mathrm{O}_{3}$ & 18.51 & 36.45 & $22.8 \pm 2.4$ & $4.4 \cdot 10^{5}$ \\
\hline
\end{tabular}

Notes: $\left[\mathrm{ArCH}_{3}\right]_{0}=0.4 ;\left[\mathrm{Mn}^{2+} \mathrm{Br}\right]_{0}=0.08 \mathrm{~mol} \cdot \mathrm{l}^{-1}$.

Table 2

The effect of manganese(II) acetate concentration on the methyl group oxidation selectivity of 4-AAT

\begin{tabular}{|c|c|c|c|}
\hline \multirow{2}{*}[\mathrm{Mn}(\mathrm{OAc})_{2}]{, $\mathrm{mol}^{-1} \mathrm{l}^{-1}$} & \multicolumn{2}{|c|}{ Yield of the reaction products, $\%$} & \multirow{2}{*}{ Selectivity of methyl group oxidation, \% } \\
\cline { 2 - 4 } & alcohol & aldehyde & 52.4 \\
\hline 0.02 & 44.5 & 7.9 & 65.0 \\
\hline 0.04 & 52.8 & 12.2 & 76.9 \\
\hline 0.06 & 57.0 & 16.9 & 85.5 \\
\hline 0.08 & 65.5 & 20.0 & 85.2 \\
\hline 0.12 & 64.7 & 20.5 & \\
\hline
\end{tabular}

Notes: $[4-\mathrm{AAT}]_{0}=0.4 ;\left[\mathrm{O}_{3}\right]_{0}=4.0 \cdot 10^{-4} ;\left[\mathrm{H}_{2} \mathrm{SO}_{4}\right]_{0}=1.0 \mathrm{~mol} \cdot \mathrm{l}^{-1} ; T=303 \mathrm{~K}$.

Selectivity for methyl group oxidation depends on the ratio of reaction rates (1-3). As one can see from Table 1 the rate constant of ozonolysis reaction is much higher than that of $\mathrm{Mn}^{3+}$ substrate oxidation. Therefore, the selective methyl group oxidation is possible only at the increased concentration of $\mathrm{Mn}^{3+}$, which is observed in practice (Table 2).

The results of kinetics studies (Table 2) explain the reason for stopping 4-AAT oxidation at the stage of forming the corresponding benzylacetate or benzylidendiacetate, since the rate of substrate oxidation with the oxidized metal form and ozone becomes slower in the order: substrate > alcohol > aldehyde.

One can observe further deepening of oxidation when potassium bromide is injected in the catalytic system $\mathrm{AC}_{2} \mathrm{O}-\mathrm{Mn}\left(\mathrm{OA}_{\mathrm{C}}\right)_{2}-\mathrm{H}_{2} \mathrm{SO}_{4}$. The process can be stopped at the stage of forming the corresponding benzaldehyde. While oxidizing 4-AAT, 4-AABDA
$(69.5 \%)$ and 4-AABA(15.2\%) have been found (Fig. 2). It should be noted that obtained acetate and acelale derivatives are readily hydrolyzed forming corresponding alcohol and aldehyde with the yield of 90-95\%.

Deepening of the oxidation in the presence of bromine ions is connected with the formation of manganbromide radical (Scheme 2(6)), which is more active than $\mathrm{Mn}$ (III) (Table 1), and what is more important, it can involve into the oxidation aromatic alcohol to corresponding aldehyde. This allows not only to deepen oxidation, but almost twice reduce the optimal concentration of manganese(II) acetate.

According to the existing notions of oxidation reactions of arenes with molecular oxygen and ozone and the kinetic data obtained, the following scheme of selective oxidation of 4-AAT in acetic and hydride (Scheme 2) is to be expected: 


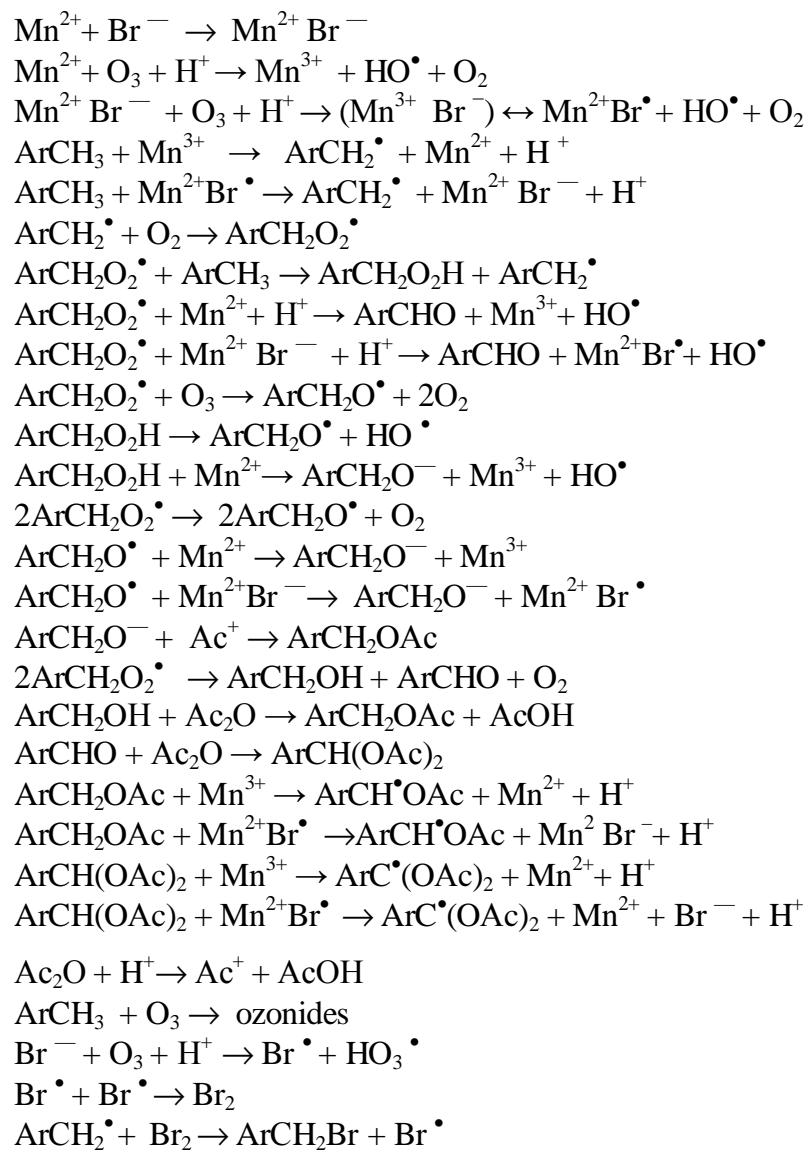

\section{Scheme 2}

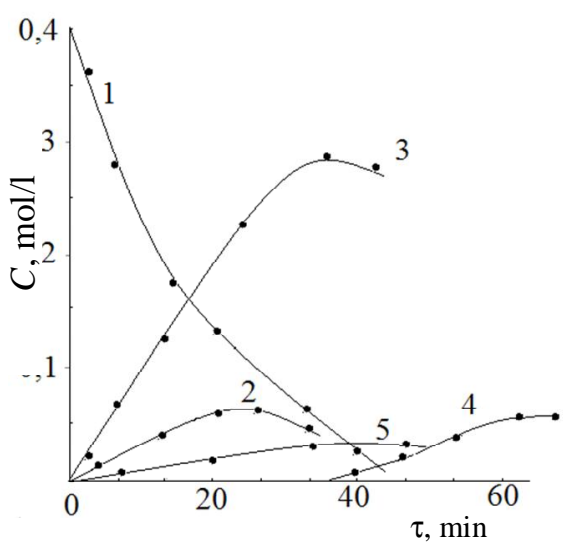

If the system is catalyzed with manganese(II) acetate, the active form of catalyst is $\mathrm{Mn}$ (III), which involves the substrate to methyl group oxidation with the formation of benzyl radical (7). The introduction of potassium bromide in the oxidation scheme leads to the formation of manganbromide ion-radical $(4,6)$, which is more active than $\mathrm{Mn}(\mathrm{III})$; benzyl radical is formed mainly according to the reaction (8). When $\left[\mathrm{O}_{2}\right]>>\left[\mathrm{O}_{3}\right] \approx 20$,
Fig. 2. Kinetics of 4-AAT(1) oxidation in acetic anhydride at $303 \mathrm{~K}$ in the presence of sulfuric acid and manganbromide catalyst: 4-AABA (2); 4-AABDA (3); 4-AABA (4) and 4-acetamidobenzylbromide (5).

$\left[\mathrm{ArCH}_{3}\right]_{0}=0.4 ;[\mathrm{KBr}]=0.10 ;\left[\mathrm{Mn}\left(\mathrm{OA}_{\mathrm{c}}\right)_{2}\right]_{0}=0.10$; $\left[\mathrm{H}_{2} \mathrm{SO}_{4}\right]_{0}=1.0 ;\left[\mathrm{O}_{3}\right]_{0}=4.0 \cdot 10^{-4} \mathrm{~mol} \cdot \mathrm{l}^{-1} ; V_{p}=0.011$ benzyl radicals are transformed further mainly in peroxide radicals (9). Their further transformation according to the existing scheme is possible only if the chain length $v=$ $=r_{p} / r_{i} \gg 1\left(r_{i}-\right.$ initiation reaction rate, $r_{p}-$ chain extension reaction rate). Under the experimental conditions the limiting stage of selective oxidation is reaction (6) and among the reactions of chain extension (10-13), in the case of oxidation chain scheme, the highest rate has the 
reaction (12). The evaluation calculations have shown that chain length value obtained is less than 1 , which means that the oxidation process occurs mainly according to the ion-radical non-chain mechanism. The formation of aldehyde probably occurs according to the reaction scheme $(11,12,20-22)$. Aromatic alcohol, under these conditions, is accumulated due to the reactions (16-21) and further may be oxidized to benzyl radicals $(23,24)$ with their subsequent transformation according to the schemes mentioned above.

\section{Conclusions}

It has been identified that the catalyst manganese(II) acetate (4-AABA-65.5\%; 4-AABDA$20.0 \%$ ) and its mixture with potassium bromide (4-AABDA-69.5\%, 4-AABA-15.2\%) plays the decisive role in achieving the required depth and selectivity relative to the methyl group oxidation of 4-AAT. It has been shown that catalytic oxidation with ozone occurs mainly according to non-chain mechanism. It has been found that ozone acts as a generator of the metal oxidized form, which is involved in the oxidation initiation reactions, bromine ions accelerating electron transfer from the substrate to the metal ion. From the experimental results, the optimal conditions for the preparation of 4-AABA and 4-AABDA have been determined and the methods of synthesis of these products have been proposed.

\section{References}

[1] Lisitsyin V.: Khimiya i Tehnologiya Promezhutochnykh Produktov. Khimiya, Leningrad, 1987.
[2] Shvayka O.: Osnovy Syntezu Likars'kykh Rechovyn. Skhidnyy vydavnychyy dim, Donetsk 2002.

[3] Tyagi O., Yadav M.: Synthetic Dyes. Anmol Publications Pvt. Ltd, New Dehli 2002.

[4] Galstyan S., Tyupalo N., Galstyan A.: Pet. Chem., 2011, 51,

212. https://doi.org/10.1134/S0965544111030042

[5] Andreev P., Galstyan G., Galstyan A.: Zh. Organ. Khim., 2004, 40, 1678.

[6] Galstyan G., Galstyan T., Mikulenko L.: Kinetika i Kataliz, 1994, 35, 255.

[7] Galstyan T., Galstyan A., Marshalok H. : Przemysł Chemiczny, 2017, 96, 558. https://doi.org/10.15199/62.2017.3.14

[8] Sedykh A., Galstyan A.: Zh. Prikl. Khim., 2006, 79, 125.

[9] Galstyan A., Galstyan S., Lysak V.: Kinet. Catal., 2011, 52, 493. https://doi.org/10.1134/S0023158411040033

[10] Galstyan A., Marshalok H., Galstyan G.: Przemysł Chemiczny, 2016, 95, 828. https://doi.org/10.15199/62.2016.4.23

Received: August 11, 2017 /Revised: August 31, 2017 / Accepted: October 23, 2017

\section{ДОСЛІДЖЕННЯ ПРОЦЕСУ РІДИННОФАЗНОГО СЕЛЕКТИВНОГО ОКИСНЕННЯ 4-АМІНОТОЛУЕНУ ОЗОНОМ}

\begin{abstract}
Анотація. За результатами дослідження кінетичних закономірностей $i$ механізму процесу каталітичного окиснення 4-амінотолуену озоном у рідкій фазі, розроблено основи технології синтезу 4-амінобензилового спирту та 4-амінобензальдегіду. Показано, щуо за умов озонування в розчині оцтового ангідриду в присутності сульфатної кислоти, манган(II) ацетату або його сумімі з калій бромідом зупинити окиснення можна на стадії утворення 4-амінобензилового спирту або альдегіду. Вивчено технологічні параметри $i$ встановлено оптимальні умови реалізаиії процесів.
\end{abstract}

Ключові слова: 4-ацетамідотолуен, каталізатор, 4амінотолуен, окиснення, озон. 